\title{
Alpha-2C Adrenergic Receptor
}

National Cancer Institute

\section{Source}

National Cancer Institute. Alpha-2C Adrenergic Receptor. NCI Thesaurus. Code C107615.

Alpha-2C adrenergic receptor (462 aa, $\sim 50 \mathrm{kDa}$ ) is encoded by the human ADRA2C gene.

This protein is involved in catecholamine-induced regulation of adenylate cyclase signaling. 